\title{
Label-free Protein Quantification by LC/MS
}

National Cancer Institute

\section{Source}

National Cancer Institute. Label-free Protein Quantification by LC/MS. NCI Thesaurus.

Code C161825.

A method for quantitating proteins in label-free samples subjected to liquid

chromatography-mass spectrometry (LC/MS). 